\title{
Author Correction: Threats to global food security from emerging fungal and oomycete crop pathogens
}

Helen N. Fones (D), Daniel P. Bebber (D), Thomas M. Chaloner, William T. Kay (D), Gero Steinberg and Sarah J. Gurr (D)

Correction to: Nature Food https://doi.org/10.1038/s43016-020-0075-0, published online 8 June 2020.

In the version of this Review Article originally published, in the heading "Examples of emerging pathogens threatening staple and commodity crops", 'threatening' was misspelt as 'threating'. In Fig. 2, the purple dot over Grande Terre in the Caribbean should have been positioned over Grande Terre in the Mayotte region of the Indian Ocean, and in the legend, in the label " 50 to > 25 million tonnes", ' 50 ' should have been ' 5 '; the original and corrected Fig. 2 are shown below. In Fig. 2 caption, ref. 81 was mistakenly not cited; "refs. 80,8291" should have been "refs. 80-91". In the sentence beginning "It has now appeared in South America...”, refs. 80 and 91 weren't cited; "(refs. 81-90)" should have been "(refs. 80-91)". All versions of the Review Article have been amended. 


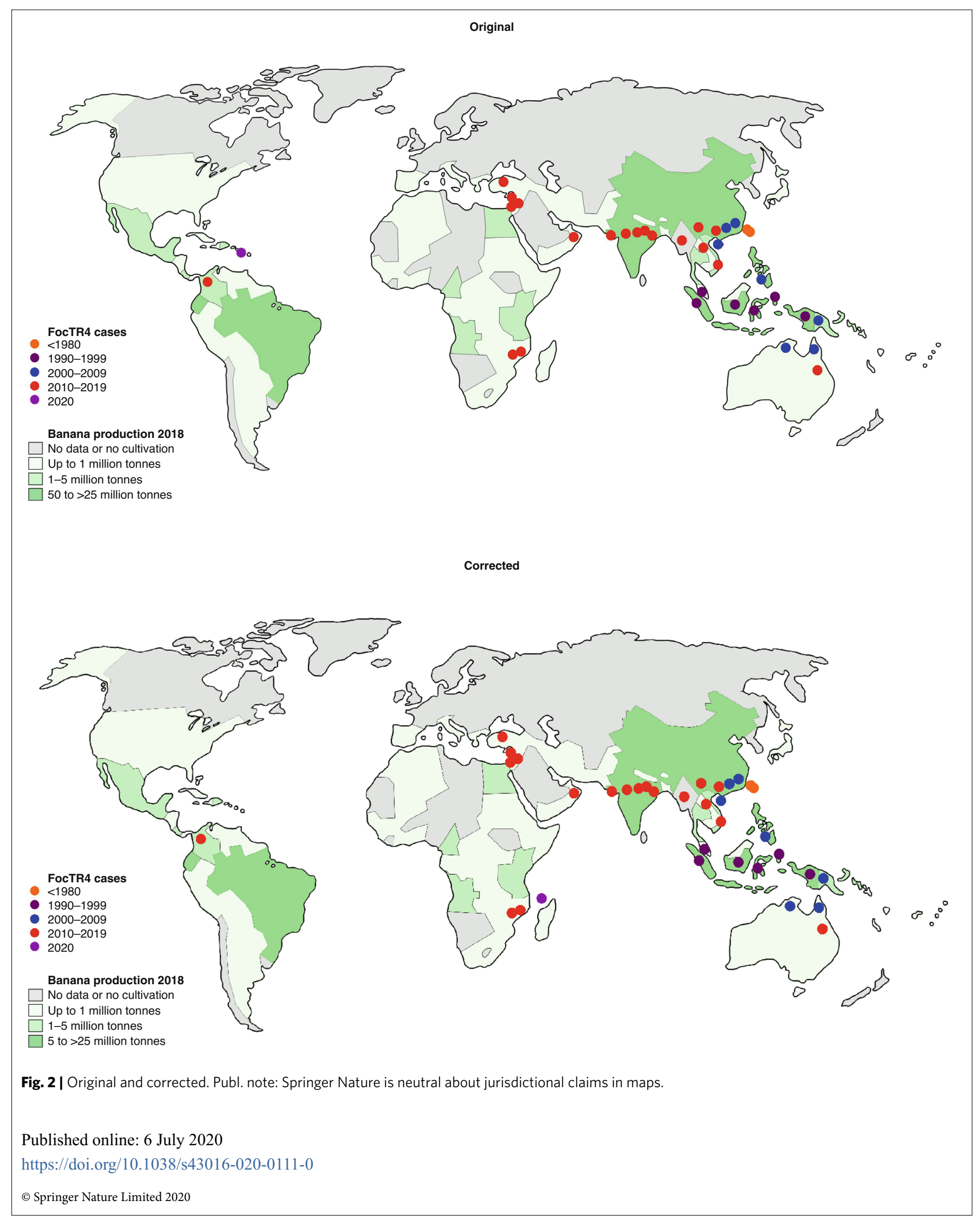

